\title{
Condições da ação no processo penal
}

\author{
Carlos Menegat Filho*
}

Segundo a doutrina de Liebman, a qual influenciou a dogmática processual brasileira, são estas as condições da ação: a possibilidade jurídica do pedido, o interesse em agir e a legitimação para a causa.

Discute-se se elas abarcariam o mérito da ação ou não. Embora alguns juristas possam defender essa tese, ela não nos parece correta, pois, ao estudarmos as condições da ação, supõe-se que, mesmo estando presentes aquelas condições, ainda é necessário um segundo momento, ou seja, um julgamento, de procedência ou não do pedido, produzindo a coisa julgada material.

Portanto, a inexistência de condições da ação terá como consequiência a carência da ação, mas que todavia não produzirá coisa julgada material, podendo, pois, ser novamente proposta se for completado o elemento da ação faltante. Pelo exposto, não podemos colocar as condições da ação como fazendo parte do mérito, já que este tem em sua base a coisa julgada.

Assim, onde deveríamos inseri-las? Pensamos que o seu lugar ideal seria entre os pressupostos processuais e $o$ mérito propriamente dito, numa categoria intermediária, podendo então ter tratamento diferenciado, consistindo na existência da procedibilidade do processo, bem como na inexistência de coisa julgada material.

No exame da verificação das condições da ação, afloram duas teorias doutrinárias: a) que o exame da ação deva ser feito à luz da realidade dos fatos e b) que esse exame deva ser feito à luz das alegações do autor, tão somente.

No que tange à segunda posição divergimos frontalmente, eis que as

* Professor de Ciências Penais na Faculdade de Direito da UFRGS. 
afirmações constantes da peça inicial e que dão origem ao processo devem ser consideradas como meras afirmações de direito. Assim, a existência ou não das condições da ação devem ser analisadas à verdade dos autos, como um todo e não somente nas alegações do autor.

Nessa mesma linha de raciocínio, destaca Ada Pellegrini Grinover: "Não é possível rotular a mesma circunstância, ora como condição de admissibilidade da ação, ora como mérito, justificando as decisões de uma ou de outra forma, consoante o momento procedimental em que forem proferidos. Não acolhemos a teoria da prespectazzione: as condições da ação não resultam da simples alegação do autor, mas da verdadeira situação trazida a julgamento".

Ao darmos essa visão panorâmica e geral nas. condições da ação no processo, podemos trabalhar melhor os seus elementos, mais especificamente no processo penal, pois sua natureza diverge, em alguns pontos, do processo civil. E notaremos essas diferenças na própria classificação dos elementos das condições da ação, já que o processo penal não segue os três elementos clássicos da teoria de Liebman, ou seja:

a) Possibilidade jurídica do pedido;

b) Interesse em agir;

c) Legitimação para a causa.
Contudo, é preciso avaliar um quarto elemento: a justa causa.

Então, urge que analisemos mais precisamente esses elementos:

\section{POSSIBILIDADE JURÍDICA DO PEDIDO}

A idéia da possibilidade jurídica do pedido como condição da ação se deve a Liebman, que com esse termo pretendeu conceituar a idéia de possibilidade em abstrato do provimento solicitado. No Direito Penal, a aplicação da própria lei obedece ao princípio da legalidade, ou seja: "Não há crime sem lei anterior que o defina. Não há pena sem prévia cominação legal".

Logo, para aplicar-se uma pena privativa de liberdade, a conduta do autor tem que estar tipificada como crime, quer definindo a conduta, quer impondo a sansão penal e, previamente, impondo uma pena. Sem essas condições seria impossível iniciar-se uma ação penal. Imaginemos um promotor de justiça iniciar uma ação penal denunciando alguém por clonagem de seres vivos. Ora, se tal fato não está previsto no CP como crime, há absoluta impossibilidade de sua existência.

Da mesma forma se considera como impossibilidade jurídica do pedido, a ação proposta com falta do ato prévio. Assim, a ação penal pública condicionada exige a representação da vítima ou

1 GRINOVER, Ada Pellegrini. As condições da ação penal. São Paulo: Bushatsky, 1997, p. 126. 
a requisição do ministro da Justiça, pois sem esses elementos faltarão condições à ação, já que inexiste possibilidade jurídica do pedido, não podendo ter prosseguimento a ação penal.

\section{INTERESSE EM AGIR}

Quanto ao "interesse em agir", assim se referia Chiovenda: "sem a intervenção dos órgãos disciplinadores o autor sofreria um dano injusto."2 Liebman assim pontificava: "Consiste no interesse de obter o provimento demandado". ${ }^{3}$

Podemos resumir, então, o interesse de agir em necessidade e adequação do provimento solicitado. Na lição do eminente jurista José Maria Rosa Tesheiner em sua valiosa obra Elementos para uma Teoria Geral do Processo, ${ }^{4}$ aponta o "interesse em agir" como necessidade para obter através do processo a proteção do interesse substancial, pressupondo, por conseqüência, a lesão desse interesse e a idoneidade do provimento solicitado.

Segue o mestre: "Às vezes não é tanto a necessidade quanto a utilidade que se encontra na base do interesse de agir. Pode ocorrer, por exemplo, que o poder executivo, embora podendo emitir e executar ato administrativo, prefira, por motivos políticos solicitar o provimento jurisdicional como tem mandado de reintegração de posse em terras públicas invadidas. Não há necessidade, mas utilidade, e esta basta para que se componha o interesse em agir".

No processo penal, o interesse em agir encontra-se no momento em que é ofertada a própria ação, pois não é possível impor uma sanção pènal sem o devido processo penal. Cabe aqui lembrar o ensinamento de Ada Pellegrini Grinover de que "no interesse de agir não deve tratar a do direito material alegado (pedido idôneo amparado em provas) já que são distintos o direito de ação e o direito material."'s

\section{LEGITIMAÇÃO PARA A CAUSA}

A ação só pode ser exercida pelos seus titulares, pois eles é que são as pessoas legítimas a proporem a ação (legitimação ativa) contra outros (legitimação passiva). Então vemos que existem duas legitimações: a passiva e a ativa. E quem são essas pessoas legítimas? No dizer do professor

2 CHIOVENDA, Giuseppe. Instituições de direito processual civil. São Paulo: Saraiva, [s.d.], v. 1, p 181, 1365.

3 LIEBMAN, Enrico Túlio, Manual de direito processual civil . [s.n.t.], v. 1.

4 TESHEINER, José Maria Rosa. Elementos para uma teoria geral do processo. São Paulo: Saraiva, 1993.

5 GRINOVER, As Condições... 
Tourinho Filho, ${ }^{6}$ são aquelas que são titulares de uma situação jurídica material.

No processo penal, a titularidade se dará pela lei ou a titularidade é vista em face do conflito de interesses e não do direito que se pretende reconhecer, ou seja, quando o interesse maior for o público, a ação penal será pública e o titular o MP; quando for privado, o interesse maior será privado e então o - titular será o ofendido ou seus representantes.

A legitimação passiva, por sua vez, obriga que o réu seja também legitimado para a ação, isto é, deve ele poder receber a ação penal que é proposta. Assim, não haveria legitimação para a causa de uma ação penal de roubo proposta pelo Ministério Público, em que o réu fosse menor de dezoito anos.

\section{JUSTA CAUSA}

Este é o quarto elemento das condições da ação penal. O Processo Penal apresenta esse elemento que não faz parte da doutrina do Processo Cível pela própria natureza jurídica do Processo Penal. O Direito Penal é visto como a ultima ratio, sendo que o Processo Penal já representa uma forma de penalidade, pois desde o início da ação penal até o julgamento desta, o réu, sujeito passivo na relação processual penal, será exposto a execração pública até provar a sua inocência, podendo chegar à condenação e, como conseqüência, perder um dos direitos básicos do ser humano, que é a liberdade, o direito de ir, vir, ficar e permanecer, sendo muitas vezes, colocado em cárceres que destroem a integridade física e psíquica do homem, fazendo com que a re-socialização do indivíduo e sua recuperação para viver em sociedade, que é um dos objetos na execução penal, se torne letra morta.

Por isso é que se reveste de importância o processo penal, mormente no que tange às condições da ação, pois a simples instauração do processo como já vimos pelas suas conseqüências, atinge a dignidade humana. Não podemos admitir que qualquer fato permita essas conseqüências que abordamos. A ação penal, portanto, só deve ser desencadeada com fatos inequívocos, ou seja, elementos que permitam concluir pelo fumus boni juris, sem o qual não existirá justa causa, não podendo desencadear a ação penal.

Mas o que é a justa causa? São provas mínimas que devem estar presentes quando do oferecimento da ação penal.

E que provas são essas? Prova da materialidade e indícios suficientes da autoria, pois sem essas provas não poderá ser instaurado o Processo Penal, face à evidência da coação ilegal. (648, I do CPP).

6 TOURINHO FILHO, Fernando da Costa. Manual do processo penal. São Paulo: Saraiva, 2001, p. 136. 
A prova da materialidade é aquela que demonstra a consumação do crime, admitindo-se a forma indireta.

Exemplificando: a materialidade num homicídio é o auto de necropsia; a de lesões corporais graves é o auto de corpo de delito. Tais provas, nesses delitos, devem necessariamente estar presentes no oferecimento da denúncia.

E se não existirem tais provas? Deve, então, ser feito de maneira indireta. Por exemplo, através de testemunhas que viram o homicídio ou as lesões corporais. Esse tipo de prova, inclusive, está previsto no art. 158 do CPP.

Então, seja de forma direta ou indireta ela deve vir aos autos. O que não pode acontecer é a falta de prova de materialidade. Exemplo: todas as pessoas numa certa comunidade acham que foi determinada pessoa que cometeu um homicídio, só que o corpo da vítima nunca foi achado e nem teve testemunhas presenciais para realizar o auto de necropsia indireto; assim, não é possível instaurar a ação penal por falta de justa causa no que tange à materialidade.

Mas não basta a materialidade, deve haver indícios suficientes de autoria.

E quando há indícios suficientes de autoria? Bem, nesse caso, existe um critério subjetivo do juiz; todavia, podemos afirmar que são aquelas provas mínimas que apontam o acusado como sendo o autor do crime imputado.

Desta forma, não basta apenas termos a prova da materialidade. Exemplo: o auto de necropsia. É necessário que tenhamos elementos mínimos (seja testemunhal, pericial ou quaisquer outras provas admitidas em direito) que apontem para o acusado como sendo o autor do crime.

É importante ressaltar que a justa causa (prova da materialidade e indícios suficientes de autoria) não diz respeito ao mérito. $O$ juiz não está antecipando qualquer tipo de julgamento, ele apenas está fazendo um juízo de admissibilidade, ou seja, observando se esse requisito se encontra na proposição da ação para que possa ser recebida e processada.

Podemos, então, colocar a justa causa como elemento, independente dos demais da teoria clássica, apresentada por Liebman, em virtude da natureza do objeto do Processo Penal.

Senão vejamos:

Admitamos que Alfredo, Promotor de Justiça na primeira vara do Tribunal do Júri de Porto Alegre-RS, tenha uma discussão áspera com Luiz, o advogado, na saída do fórum. Então, Alfredo resolve "denunciar" Luiz por um suposto homicídio doloso, descrevendo todas as circunstâncias, conforme art. 41 do CPP, sem, no entanto, demonstrar a materialidade ou indícios de autoria, entregando, mesmo assim, a denúncia.

No presente caso podemos, em tese, vislumbrar:

a) Há possibilidade jurídica do pedido, já que o homicídio está previsto no art. $121, \S 1^{\circ}$ do CP.

b) O interesse em agir está implícito na própria ação penal, presente o seu 
interesse no provimento jurisdicional, já que em tese um crime praticado e em não se vislumbrando excludente, deve ser punido.

c) A legitimação também está presente aqui - pelo representante do MP, no caso uma ação penal pública incondicionada.

Portanto, se analisarmos apenas pela ótica da teoria clássica, o juiz deveria, em tese, receber a denúncia proposta e citar o réu para se defender,

\section{REFERÊNCIAS}

CHIOVENDA, Giuseppe. Institulações de direito processual civil. São Paulo: Saraiva, [s.d.]. v. 1.

GRINOVER, Ada Pellegrini. As condições da ação penal. São Paulo: Bushatsky, 1997. o que evidentemente seria um absurdo. Por isso defendemos a existência do quarto elemento, que é a justa causa existente no processo penal, tendo em vista as suas peculiaridades.

No presente caso, não estariam contidas as condições da ação, justamente pela falta de justa causa, não podendo o magistrado receber a denúncia e dar início à ação penal, porque, caso o fizesse, estaria incorrendo em coação ilegal.

LIEBMAN, Enrico Túlio, Manual de direito processual civil . [s.n.t.]. v. 1. TESHEINER, José Maria Rosa. Elementos para uma teoria geral do processo. São Paulo: Saraiva, 1993. TOURINHO FILHO, Fernando da Costa. Manual do processo penal. São Paulo: Saraiva, 2001. 